\title{
ANALYSIS OF THE STRUCTURING OF ASSESSMENT ACTIVITIES IN TECHNICAL EDUCATION AT PRIMARY SCHOOL
}

Pavlína $\check{C}$ ÁSTKOVA * Univerzita Palackého v Olomouci, Česká republika Dominika PROVÁZKOVÁ STOLINSKÁ, Univerzita Palackého v Olomouci, Česká republika

Přijato: 7. 5. 2017 / Akceptováno: 16. 6. 2017

Typ článku: Výzkumný článek

DOI: $10.5507 /$ jtie.2017.011

Abstract: The article deals with the assessment of the pupil in technical education at primary school. The basis is the effort to modernize the system of assessment at the level of pupils. We perceive evaluation process as an integral part of everyday pedagogical communication and interaction. That's why we approach to them from a research point of view. Part of the paper is the presentation of partial results of a research survey focused on the development of pupil selfassessment at primary school. For the purposes of identifying, categorizing and analyzing the evaluating statements of the teacher and pupils, the specific coding was used based on the Bellack and the Flanders interaction analysis methods.

Key words: assessment, primary school, technical education, research, communication and interaction.

\section{ANALÝZA STRUKTUROVÁNÍ HODNOTÍCÍCH ČINNOSTÍ V TECHNICKÉ VÝCHOVĚ NA PRIMÁRNÍ ŠKOLE}

Abstrakt: Článek se zabývá problematikou hodnocení žáka v technické výchově na primárni škole. Téma je řšeno v kontextu snah o modernizaci systému hodnocení na úrovni žákù. Hodnotici procesy jsou autorkami vnímány jako nedílná součást každodenni pedagogické komunikace a interakce, proto je k nim takto přistupováno i z výzkumného hlediska. Součástí stati je prezentace dilčích výsledků výzkumného šetrení zaměřného na rozvoj sebehodnocení žáka na primárni škole. Pro potřeby identifikace, kategorizace a analýzy hodnoticich výroků učitele a žáků bylo použito specifické kódování vycházejicí z principů Bellackovy a Flandersovy metody interakčni analýzy.

Klíčová slova: hodnocení, primární škola, technická výchova, výzkum, komunikace a interakce.

*Autor pro korespondenci: pavlina.castkova@upol.cz 


\section{1 Úvod}

$\mathrm{V}$ reakci na změny (nejen) $\mathrm{v}$ politických a společenských systémech vznikla kurikulární reforma, a to jak v jiných evropských zemích, tak u nás (po r. 1989). Vezmemeli v úvahu, že vzdělávání připravuje člověka pro život ve společnosti, bylo tedy zákonité, že ony změny se musí projevit také v oblasti hodnocení žáků. Na potřebu změny přístupu k hodnocení již upozorňovala tzv. Bílá kniha, ve které byl zdůrazňován vzájemný vztah učitelů a žáků. Rovněž byl v dokumentu kladen důraz na hodnocení založeném na jasně vymezených kritériích a pravidlech, která jsou předem stanovena. Byl vysloven požadavek na vytvoření uceleného systému hodnocení žáka jako jeden z předpokladů usnadnění přechodu mezi jednotlivými stupni i pro odpovídající volbu vzdělávací dráhy. S odstupem času je možné konstatovat, že navzdory dílčím pokrokům nebyly deklarované cíle naplněny a řada plánovaných opatření byla uskutečněna v odlišné podobě.

Ve snaze stanovit aktuální základní rámec pro další rozvoj vzdělávání byla vytvořena Strategie vzdělávaci politiky $v \check{C} R$ do roku 2020. Jednou z hlavních priorit se stala modernizace systému hodnocení na úrovni žáků. Na základě toho je vysloven požadavek, aby vzdělávací systém podporoval metody hodnocení, které jsou zaměřeny na sledování individuálního pokroku každého žáka a studenta. Cílem hodnotících aktivit v oblasti základního vzdělávání, tedy i primární školy, má být poskytování zpětné vazby žákům (i učitelům) s akcentem na rozvoj formativního vzdělávání. Učitel jako jediný hodnotitel ze své podstaty nemůže postihnout komplexitu procesu hodnocení. V př́padě, že v duchu současné pedagogiky vnímáme žáka jako spolutvůrce výchovného procesu, pak je jeho participace nezbytná i při hodnocení výsledků učební činnosti. Cílem př́íspěvku je prezentovat dílčí výsledky výzkumného šetření zaměřeného na analýzu hodnotících aktivit při realizaci technické výchovy v 1 . ročníku základní školy. Jako výzkumná metoda byla zvolena interakční mikroanalýza, která je zaměřena na verbální projevy v interakci učitelžák. Při samotném sběru výzkumných dat docházelo k pozorování prvků jednotlivých typů chování prri hodnocení jejich vlivu na přijetí či nepřijetí působení žáky.

\section{Specifika hodnotících procesů v technické výchově na primární škole}

Technická výchova je primárně zaměřena na formování, osvojování a rozvíjení manuálních dovedností. Svým zaměřením umožňuje žákům získat nezbytné vědomosti, pracovní dovednosti i návyky nutné pro další vzdělávání, profesní orientaci a každodenní život. Mimo to jsou rozvíjeny osobnostní kvality žáka v oblasti myšlení, vnímání, řeči, tvořivosti, představivosti a dalších sociálních, intelektuálních i morálních vlastností. Nezbytnou součástí myšlení, resp. technického myšlení je hodnocení. Autoři J. Kropáč (st.) a J. Kropáč (ml.) (2009, s. 88) uvádí, že „,hodnotící posouzení techniky a di̊sledkü činností spojených s užitím techniky bylo a nadále bude součástí výuky technicky zaměrených predmětů na ZŠ゙، Žák nejčastěji hodnotí výsledek práce či průběh pracovní činnosti, výběr materiálů, nástrojů a nářadí, ale také souvislosti bezpečnosti práce $\mathrm{s}$ technikou. Technická výchova na primární škole představuje určitý předstupeň „hodnocení techniky“, formuje žákovu osobnost a je důležitým výchovným činitelem. (Novotný, Honzíková, 2014; Kožuchová, 1993, Kropáč, Kropáč, Plischke, 2010)

Problematika hodnocení v technické výchově je v mnoha ohledech složitější než hodnocení v kognitivně zaměřených předmětech. Pětistupňová klasifikační škála, jako nejčastější způsob hodnocení na primární škole může představovat určité omezení. V edukační realitě klasifikace často vyjadřuje pouze výslednou „nálepku“ žákova výrobku, 
aniž by zohledňovala širší souvislosti (př́ípravu a průběh žákovy práce, jeho snahu, zaujetí i individuální limity). Mezi specifické prvky hodnocení v technické výchově je možné zařadit např. přesnost ( $\mathrm{v}$ myšlení i $\mathrm{v}$ praktické realizaci), technologickou kázeň (dodržování pracovních postupů), odpovědnost za správnost provedení a kvalitu práce (výrobku), respekt a vědomí nutnosti dodržovat specifické pracovní zásady (hygieny a bezpečnosti práce, pořádku na pracovišti), hospodárné zacházení s používanými materiály i s nářadím, $\mathrm{s}$ vlastní energií a časem, plánování a organizace (včetně dokončení práce), objektivní hodnocení průběhu i výsledků pracovní činnosti, celkový rozvoj pozitivního vztahu žáků k práci i k technickým činnostem. (Škára, 1993)

\section{Vliv komunikace na procesy hodnocení}

Podnětná komunikace a interakce mezi učitelem a žákem je základní podmínkou pro realizaci edukačního procesu v moderním pojetí. Jako významnou determinantu, která ovlivňuje úspěšnost komunikačního aktu, uvádíme především způsob komunikace. Dle běžné terminologie rozlišujeme komunikaci verbální a neverbální (nonverbální). Verbální komunikací rozumíme veškerá sdělení prostřednictvím slov. Neverbální komunikace pak verbální komunikaci doprovází a podporuje (nebo naopak oslabuje), v některých př́padech nahrazuje, dále podporuje aktivní naslouchání a reguluje hladký průběh dialogu (Allhoff, Allhoff, 2008).

Kromě tohoto tradičního př́stupu můžeme komunikaci dle P. Watzlavicka, J. B. Bavelas a D. D. Jacksona (2011) definovat jako výměnu signálů. Tyto signály dělíme na věcné a vztahové. Zatímco věcné signály nás informují o obsahu komunikace, ty vztahové poukazují na vztah, který $\mathrm{k}$ nám druhý člověk projevuje (rovnocenný nebo nerovnocenný). Podle výzkumu autorů je podíl našeho zaměření se na vztahové signály v komunikaci 91$93 \%$. Dojde-li k nedorozumění, je to častěji způsobeno problémem v oblasti vztahových signálů (spíše než věcných).

Výsledky daného výzkumu mohou mít pro učitele primární školy velký význam, protože poukazují na skutečnost, že především způsob (a ne pouze obsah) představují pro žáka výpovědní hodnotu.

Učitel jako subjekt hodnocení je ovlivněn velkým množství skutečností, které jsou součástí jeho vztahu k žákovi. Mezi zásadní determinanty patří chápání samotného žáka učitelem a jeho očekávání. Od toho se odvíjí celkové pojetí výuky (výukové strategie) a s ním i subjektivní koncepce učitelova hodnocení. Učitelovo pojetí výuky však podle Mareše (1996) vzniká postupným procesem, který je započat již v období školních let učitele, kdy vnímá a posuzuje hodnocení vlastní osoby. Dále je ovlivněno pregraduální př́pravou teoretického i praktického charakteru a $\mathrm{v}$ neposlední řadě léty vlastní pedagogické praxe.

Jedním z aspektů individuálního pojetí hodnotících strategií učitele je míra vyhraněnosti. Např. budoucí a začínající učitelé často nemají jasně vyhraněné názory na způsoby a dopady hodnocení žáků. Od toho se odvíjí další aspekt hodnotících strategií míra originality v pojetí hodnocení. Zde je možné uvést př́iklady tvořivých učitelů, kombinují různé metody hodnocení, experimentují a posuzují možnosti a dopady jednotlivých způsobů hodnocení. 


\section{Význam komunikace pro rozvoj sebehodnocení žáka primární školy}

Kvalitní komunikace mezi učitelem a žákem je jeden z klíčových faktorů osobnostně rozvíjejícího pojetí vzdělávání. Partnerský vztah mezi učitelem a žákem a komunikace založená na důvěře $\mathrm{v}$ žákovy schopnosti, jeho tvořivost a potenciality vlastního zdokonalování neznamená popření role učitele jako autority, naopak je kladen důraz na budování jeho přirozené autority, vytyčení jasných požadavků na žáka vymezování hranic a žákovské vnitřní přijetí pravidel školy vycházející z participace na jejich tvorbě. Sdílená odpovědnost učitele a žáka za výsledky vzdělávání vyplývá ze spolupodílení se na tvorbě hodnotících pravidel a kritérií. (Spilková, 2012)

Přestože je klasifikace v realitě českých škol stále pokládána za základní formu hodnocení, téměř vždy je doprovázena dalšími verbálními či neverbálními projevy učitele. Pro žáka je důležitá zpětná vazba poskytující informace o tom, do jaké míry zadaný úkol zvládl, jak postupoval a jakým způsobem může pracovat s př́ípadnou chybou. Proto by v každé učební situaci měla být klasifikace doplněna o vysvětlující komentář nebo diskusi s žákem. Slovní komentár učitele popisující průběh i výsledek práce vede žáka k uvědomění si vlastních silných i slabých stránek a formuje jeho sebepojetí. (Dvořáková in Vališová, 2007)

Kritika tradičního kvantitativního přístupu k hodnocení formou „škatulkování“ v podobě klasifikace byla důvodem zavedení slovního hodnocení. Samotné formy hodnocení však není možné označovat jako dobré či špatné. K fungování školního hodnocení je třeba účelně a vynalézavě kombinovat různé způsoby hodnocení s ohledem na konkrétní učební situaci, její průběh a cíle i individuální zvláštnosti žáka. (Kolář, Šikulová, 2009)

Z pohledu žáka spočívají výhody uplatňování slovního hodnocení především v dialogické formě komunikace, kdy žák figuruje jako partner. (Slavík, 1999) Vztah mezi učitelem a žákem na primární škole je vztah velmi osobní, kdy učitel působí na žáka svým chováním, jednáním a v kontextu hodnocení především způsobem komunikace. Učitel by měl své sdělení v podobě hodnocení vyjádřit v řeči adekvátní řečové úrovni žáka mladšího školního věku. Vzhledem k tomu, že figuruje také jako řečový vzor, je třeba, aby se vyjadřoval na kvalitativně vyšší úrovni za současného zachování srozumitelnosti obsahu. $\mathrm{V}$ roli komunikanta pak musí podněcovat žáka $\mathrm{k}$ přesnějším vyjádřením ${ }^{1}$, vyzdvihovat správně formulované hodnotící výroky a učit dovednosti naslouchat.

Z pohledu učitele je třeba brát úvahu fakt, že žák v roli komunikátora může být vystaven negativním vlivům provázejícím veřejný projev před učitelem i třídním kolektivem. Pod vlivem oficiálnosti svého sdělení žák často ztrácí svou spontaneitu a může volit formální a pro něj nepřirozené stylizace a tzv. školskou intonaci. (Nelešovská, 2005, s. 80) Hodnocení at' už druhého nebo sebe sama je vždy projevem úrovně hodnotitele. U žáků mladšího školního věku není možné očekávat, že budou hodnotící výroky vždy adekvátně formulovány a budou vycházet z kritického posouzení sledované situace. $\mathrm{Na}$ primární škole, kdy učitel působí ve všech předmětech a předává takřka veškeré znalosti, dovednosti i postoje, hrají roli především osobnostní kvality hodnotitele - učitele.

Hodnocení jako součást edukačního procesu, může být funkční pouze v případě, že bude kvalitně plnit všechny funkce. To znamená, že bude adekvátně informovat všechny jeho účastníky, motivovat žáky k učební aktivitě, stimulovat a regulovat učení,

${ }^{1} \mathrm{~V}$ kontextu technické výchovy např. $\mathrm{z}$ hlediska terminologie. 
a především povede žáky $\mathrm{k}$ sebereflexi založené na sebeanalýze a sebehodnocení. K efektivnímu rozvoji sebehodnocení žáka je nezbytné, aby učitel při vlastním hodnocení dodržoval následující doporučení (Kolář, Šikulová, 2009):

- zopakovat žákovi kritéria hodnocení a míru jejich naplnění žákem,

- na počátku popsat úspěchy žáka,

- společně s nedostatky uvést jejich pravděpodobné prŕíčiny,

- předložit žákovi návrhy k překonání zjištěných nedostatků,

- nepoužívat slovní hodnocení stroze jako verbální interpretaci známky, ale doplnit širším popisem,

- vyvarovat se nekonkrétním posuzovacím výrokům (to je pěkné, to se ti povedlo, to se mi libi, aj.),

- nehodnotit osobnost žáka (nepoužívat posuzující jazyk², vyvarovat se „nálepkování3“ a „škatulkováni“" typu chytrý, pomalý, dobře vychovaný, nešikovný, aj.; hodnotit činnost),

- neužívat „prázdných“ pochval, které jsou silně manipulativní a mohou se stát cílem žákova snažení,

- nesrovnávat žáka s ostatními, ale pouze s jeho vlastním předchozím výkonem,

- hodnotící výroky formulovat jasně a srozumitelně,

- nepoužívat rozkazovací ani podmiňovací věty,

- nepoužívat ironii a sarkasmus,

- celkově orientovat hodnocení pozitivně .

V procesu hodnocení žáka učitelem je možné zaznamenat také nedostatky a zkreslení, a to kognitivního i afektivního charakteru. Kognitivní nedostatky ze strany učitele spočívají především $\mathrm{v}$ nedostatečné znalosti hodnotících zásad, neadekvátní volbě hodnotících kritérií, neznalosti žáka a jeho osobnostních charakteristik, či neznalosti učiva. Mezi afektivní nedostatky lze řadit učitelovy subjektivní postoje vůči žákovi (zaujatost nebo předpojatost), neschopnost empatie či sklon promítat do hodnocení vlastní psychické rozpoložení. Významným faktorem je také vyjádření učitelova postoje $\mathrm{k}$ žákovu neúspěchu v situaci, kdy učitel hodnotí. ${ }^{5}$ Další zkreslení hodnocení vznikají na základě tendencí $\mathrm{k}$ mírnosti, príísnosti, průměru, vyhraněným soudům, aj.

Pokud si učitel klade za cíl rozvíjet potenciál žáka, vést ho $\mathrm{k}$ autoregulaci a pozitivně působit na jeho motivaci $\mathrm{k}$ učení, pak by měl především reflektovat vlastní hodnotící činnost. P. Gavora (2001) v této souvislosti zdůrazňuje reflexi subjektivních tendencí učitele při hodnocení žáků. To je možné prostřednictvím porovnávání vlastního hodnocení s hodnocením kolegů učitelů. Při reflektivní konfrontaci názorů na žáka může učitel odhalit vlastní miskoncepty a „zaběhlé zvyky“. Dále je vhodné používat objektivní ${ }^{6}$ pozorovatelná kritéria.

\footnotetext{
${ }^{2}$ Posuzující hodnocení neposkytuje žákovi zpětnou vazbu, která je třeba k jeho dalšímu rozvoji. Hodnocení tedy neplní svou korektivně-konativní funkci. (Košt’álová, Miková, Stang, 2012)

${ }^{3}$ Také označováno jako paušalizující hodnocení či labeling.

${ }^{4}$ Pozitivní hodnocení posiluje kladné vztahy člověka k sobě samému i ke svému okolí. Každý člověk jeví přirozenou tendenci udržovat určitou stabilitu vlastního sebeoceňování a usilovat především o pozitivní sebehodnocení. Př́istup učitele založený na pozitivním hodnocení žáka vyžaduje nahlížet na aktuální situaci i potenciality žáka (prospívajícího i neprospívajícího) optimisticky. Pozitivní př́stup k hodnocení je založen na principu podpory kladných vlastností, nikoliv na vyhledávání žákových nedostatků. Vliv pozitivního hodnocení na učební výkon žáka byl potvrzen i empiricky. (Stuchlíková, 2002)

${ }^{5} \mathrm{~V}$ takové situaci se projeví taktní či netaktní jednání učitele. (Mareš, 1979)

${ }^{6}$ Např. při analýze výsledků žákovy činnosti, uplatňovat anonymní hodnocení.
} 


\section{Výzkumné šetření}

K realizaci výzkumného šetření byla zvolen smíšený design výzkumu s využitím metody př́padové studie podle Stacka (1995), která se vyznačuje detailním studiem vnitřních aspektů určitého případu. (Hendl, 2005). Jako součást př́ípadové studie byla použita metoda interakční mikroanalýzy, která identifikuje verbální projevy v interakci učitel-žák. Původně bylo zamýšleno aplikovat Bellackovu interakční analýzu (Bellack, 1966), nicméně pro potřeby identifikace a kategorizace hodnotících výroků bylo vytvořeno vlastní kódování vycházející z principů Bellackovy a Flandersovy metody interakční analýzy (Chráska, 2007).

Výzkumné šetření bylo zaměřeno na analýzu hodnotících aktivit učitele a žáků při realizaci technické výchovy $\mathrm{v} 1$. ročníku základní školy prostřednictvím nezúčastněného strukturovaného pozorování $\mathrm{s}$ pořízením zvukového záznamu. Při samotném sběru výzkumných dat docházelo k pozorování prvků jednotlivých typů chování při hodnocení a jejich vlivu na hodnotící činnost žáků.

Pro záznam hodnotících aktivit v interakci učitel - žák bylo vytvořeno celkem jedenáct kategorií komplexně mapujících jejich činnost. Ve snaze o prezentaci dílčích výsledků výzkumného šetření autoři podrobněji analyzují společné kategorie pro učitele i žáka. Konkrétně se jedná o hodnocení z hlediska procesu učení, hodnocení z hlediska objektu hodnocení, hodnocení z hlediska způsobu komunikace, hodnocení z hlediska citového zabarvení výroku, hodnocení z hlediska zpětné vazby, hodnocení z hlediska užití jazyka. $\mathrm{V}$ rámci výzkumu bylo aplikováno přirozené kódování, které umožní zaznamenat jednotlivé hodnotící situace ve výuce i dílčí hodnotící výroky.

Bylo analyzováno celkem pět vyučovacích hodin s různou časovou dotací 2 x 90 min (hodina č. 1 a 2) a 3 x 45 min (hodina č. 3-5). Původním záměrem bylo sledovat a následně analyzovat výuku $\mathrm{v}$ pravidelných intervalech 1 x za 14 dní, nicméně plán nebyl uskutečnitelný vzhledem ke změnám v rozvrhu a k dalším školním aktivitám. Činnosti realizované v rámci pozorovaných hodin byly zaměřeny na práci s drobným technickým materiálem. Všechny hodiny byly realizovány v průběhu prvního pololetí školního roku 2016/2017 v měsících září, říjen, listopad. Třídní učitelka má vysokoškolské vzdělání, má 31 let praxe a učí trvale pouze 1 . a 2 . ročníky.

Výzkumné šetření bylo realizováno ve snaze najít odpovědi na následující výzkumné otázky:

- Kdo je nositelem dění při hodnotících aktivitách ve výuce technické výchovy?

- Jaký je charakter hodnotících činností žáka?

- Jaké typy hodnocení z hlediska komunikace se vyskytují ve výuce technické výchovy?

\subsection{Charakteristika výzkumného vzorku}

Výzkum byl realizován ve výuce Praktických činností v 1. ročníku 2016/2017 na plně organizované ZŠ sídlící v jedné z okrajových částí Prostějova. Ve třídě je celkem 33 žáků z toho 20 dívek a 13 chlapců. Integrován jeden chlapec s vadou řeči. Podpůrné opatření 1. stupně má jedna dívka, avšak podle vyjádření třídní učitelky jí běžné úkony v pracovních činnostech nečiní žádné potíže. Celkem osm žáků je po odkladu povinné školní docházky, $\mathrm{z}$ toho 5 dívek a 3 chlapci. 
5.2 Analýza dat a interpretace dílč́ch výsledků výzkumu

\begin{tabular}{|c|c|c|c|}
\hline Č́́slo hodiny & Nositel dění & Hodnotící výroky celkem & Hodnotící situace \\
\hline \multirow[t]{3}{*}{1} & $\mathrm{U}$ & 42 & \multirow{3}{*}{40} \\
\hline & Ž & 18 & \\
\hline & $\sum$ & 60 & \\
\hline \multirow[t]{3}{*}{2} & $\mathrm{U}$ & 40 & \multirow[t]{3}{*}{40} \\
\hline & Ž & 5 & \\
\hline & $\sum$ & 45 & \\
\hline \multirow[t]{3}{*}{3} & $\bar{U}$ & 11 & \multirow[t]{3}{*}{11} \\
\hline & Ž & 4 & \\
\hline & $\sum$ & 15 & \\
\hline \multirow[t]{3}{*}{4} & $\bar{U}$ & 15 & \multirow[t]{3}{*}{15} \\
\hline & $\bar{Z}$ & 5 & \\
\hline & $\sum$ & 20 & \\
\hline \multirow[t]{3}{*}{5} & $\mathrm{U}$ & 8 & \multirow[t]{3}{*}{7} \\
\hline & Ž & 1 & \\
\hline & $\sum$ & 9 & \\
\hline \multirow[t]{3}{*}{ Celkem } & $\vec{U}$ & 116 & \multirow[t]{3}{*}{113} \\
\hline & Ž & 33 & \\
\hline & $\sum$ & 149 & \\
\hline
\end{tabular}

Tab. č. 1: Počet hodnotících situací a výroků

V rámci pozorovaných hodin bylo zaznamenáno celkem 113 hodnotících situací, ve kterých bylo vysloveno celkem 149 hodnotících výrokủ, kam zařazujeme i dotazování či výzvu učitele za účelem hodnocení. Učitel vyslovil 116 hodnotících výroků a celkem 33 výroků vyslovili žáci. $Z$ tabulky je patrný rozdíl mezi množstvím hodnotících výroků v pozorovaných výukových hodinách. První dvě hodiny byly s časovou dotací 90 minut, zbylé tři hodiny trvaly pouze 45 minut.

\begin{tabular}{|c|c|c|c|c|}
\hline Číslo hodiny & Nositel dění & Formativní hodnocení & $\begin{array}{l}\text { Sumativní } \\
\text { hodnocení }\end{array}$ & Celkem \\
\hline \multirow[t]{3}{*}{1} & $\mathrm{U}$ & 21 & 5 & 26 \\
\hline & Ž & 3 & 14 & 17 \\
\hline & $\sum$ & 24 & 19 & 43 \\
\hline \multirow[t]{3}{*}{2} & $\mathrm{U}$ & 13 & 25 & 38 \\
\hline & Ž & 2 & 3 & 5 \\
\hline & $\sum$ & 15 & 28 & 43 \\
\hline \multirow[t]{3}{*}{3} & $\mathrm{U}$ & 3 & 8 & 11 \\
\hline & Ž & 1 & 4 & 5 \\
\hline & $\sum$ & 4 & 12 & 16 \\
\hline \multirow[t]{3}{*}{4} & $\mathrm{U}$ & 1 & 6 & 7 \\
\hline & Ž & 0 & 0 & 0 \\
\hline & $\sum$ & 1 & 6 & 7 \\
\hline
\end{tabular}




\begin{tabular}{|c|c|c|c|c|}
\hline \multirow{3}{*}{5} & $\mathrm{U}$ & 40 & 53 & 93 \\
\cline { 2 - 5 } & $\breve{Z}$ & 8 & 24 & 32 \\
\cline { 2 - 5 } & $\Sigma$ & 48 & 77 & 125 \\
\hline
\end{tabular}

Tab. č. 2: Hodnotici výroky z hlediska procesu učení

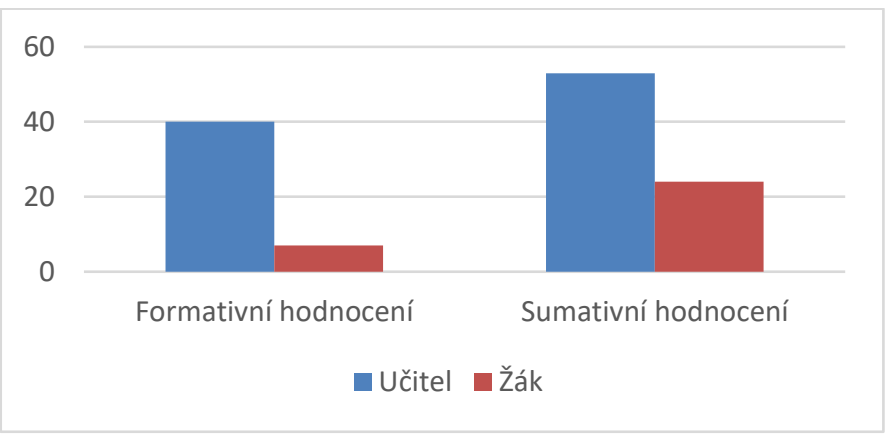

Graf č. 2: Celkový počet hodnotícich výroků z hlediska procesu učení

V pozorovaných hodinách bylo identifikováno celkem 47 formativně a 77 sumativně formulovaných výroků. $Z$ uvedeného počtu bylo 40 formativně orientovaných výroků vysloveno učitelem a 7 výrokủ žáky. V kategorii sumativních hodnotících výroků opět převažovaly výpovědi učitele -53 nad výroky žáků -24 .

\begin{tabular}{|c|c|c|c|c|c|c|}
\hline $\begin{array}{c}\text { Číslo } \\
\text { hodiny }\end{array}$ & $\begin{array}{c}\text { Nositel } \\
\text { dění }\end{array}$ & $\begin{array}{l}\text { Hodn. ž. - } \\
\text { dívka }\end{array}$ & $\begin{array}{c}\text { Hodn.ž. - } \\
\text { chlapec }\end{array}$ & $\begin{array}{l}\text { Hodnocení } \\
\text { skupiny } \\
\text { žáků/tř́́dy }\end{array}$ & $\begin{array}{c}\text { Hodnocení } \\
\text { anonymní, } \\
\text { neurčité }\end{array}$ & Celkem \\
\hline \multirow[t]{3}{*}{1} & $\mathrm{U}$ & 12 & 6 & 2 & 5 & 25 \\
\hline & $\bar{Z}$ & 0 & 2 & 0 & 15 & 17 \\
\hline & $\sum$ & 12 & 8 & 2 & 20 & 42 \\
\hline \multirow[t]{3}{*}{2} & $\overrightarrow{\mathrm{U}}$ & 14 & 12 & 8 & 5 & 39 \\
\hline & Ž & 1 & 1 & 3 & 0 & 5 \\
\hline & $\sum$ & 14 & 13 & 11 & 5 & 44 \\
\hline \multirow[t]{3}{*}{3} & $\mathrm{U}$ & 5 & 1 & 4 & 2 & 12 \\
\hline & Ž & 0 & 0 & 4 & 0 & 4 \\
\hline & $\sum$ & 4 & 1 & 8 & 2 & 16 \\
\hline \multirow[t]{3}{*}{4} & $\mathrm{U}$ & 7 & 1 & 0 & 2 & 10 \\
\hline & Ž & 0 & 1 & 0 & 4 & 5 \\
\hline & $\sum$ & 7 & 2 & 0 & 6 & 15 \\
\hline \multirow[t]{3}{*}{5} & $\mathrm{U}$ & 2 & 3 & 2 & 0 & 7 \\
\hline & Ž & 0 & 0 & 1 & 0 & 1 \\
\hline & $\sum$ & 2 & 3 & 3 & 0 & 8 \\
\hline
\end{tabular}

Tab. č. 3: Hodnotící výroky z hlediska objektu hodnoceni 


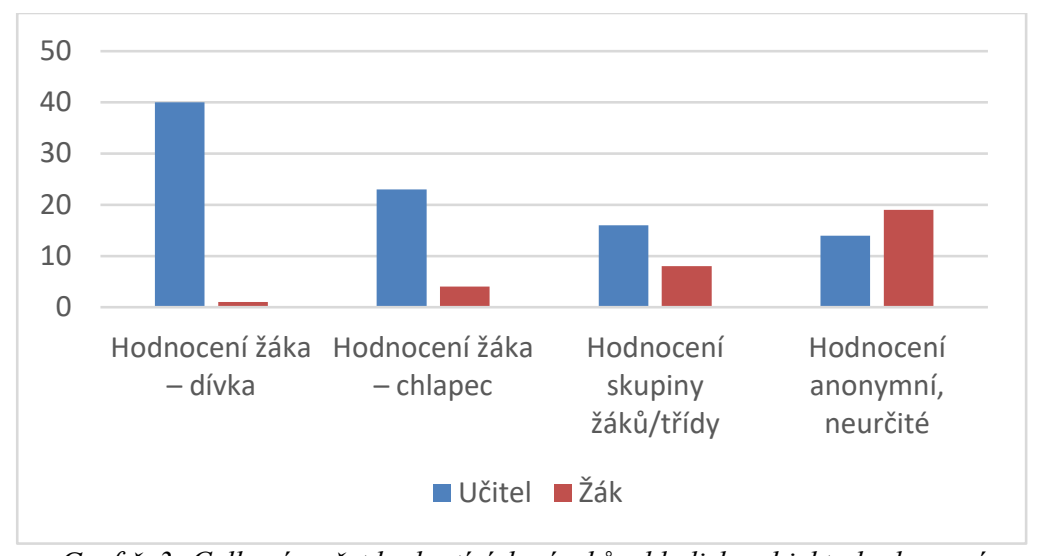

Graf č. 3: Celkový počet hodnotícich výroků z hlediska objektu hodnocení

Ve sledované výuce bylo souhrnně identifikováno 125 hodnotících výroků, 93 vyslovil učitel a 32 žáci. $Z$ toho 41 výpovědí bylo směrováno na dívky, 27 výpovědí na chlapce, 24 hodnocení třídy nebo skupiny žáků a 33 hodnocení anonymní (tzn. pro výzkumníka nebylo jasné kterému žákovy je adresováno). Největší rozdíl mezi počtem hodnotících výroků učitele a žáků byl patrný u hodnocení dívek. Učitel hodnotil dívky 38 krát, zatímco žáci pouze jednou. Z celkového počtu 28 hodnocení žáka - chlapce vyslovil učitel 22 výroků a žáci 4. Při hodnocení skupiny žáků byly poměry mezi učitelem a žáky vyrovnanější než $\mathrm{v}$ předchozích případech. Z celkových 24 hodnotících tvrzení bylo vysloveno 16 učitelem a 8 žáky. V prŕípadě anonymního hodnocení byl počet hodnotících výroků žáků vyšší než počet hodnocení učitele. Ve sledovaných hodinách bylo vysloveno celkem 33 anonymních hodnocení a z toho 19 žáky a 14 učitelem.

\begin{tabular}{|c|c|c|c|c|c|}
\hline $\begin{array}{l}\text { Číslo } \\
\text { hodiny }\end{array}$ & $\begin{array}{l}\text { Nositel } \\
\text { dění }\end{array}$ & $\begin{array}{l}\text { Slovní } \\
\text { hodnocení } \\
\text { jednoslovné }\end{array}$ & $\begin{array}{l}\text { Slovní } \\
\text { hodnocení } \\
\text { víceslovné }\end{array}$ & $\begin{array}{l}\text { Neverbální } \\
\text { hodnocení }\end{array}$ & Celkem \\
\hline \multirow[t]{3}{*}{1} & $\mathrm{U}$ & 4 & 13 & 0 & 17 \\
\hline & Ž & 7 & 10 & 0 & 17 \\
\hline & $\sum$ & 11 & 23 & 0 & 34 \\
\hline \multirow[t]{3}{*}{2} & $\mathrm{U}$ & 22 & 16 & 0 & 38 \\
\hline & $\bar{Z}$ & 0 & 2 & 3 & 5 \\
\hline & $\sum$ & 22 & 18 & 3 & 43 \\
\hline \multirow[t]{3}{*}{3} & $\mathrm{U}$ & 6 & 5 & 0 & 11 \\
\hline & Ž & 0 & 0 & 4 & 4 \\
\hline & $\sum$ & 6 & 5 & 4 & 15 \\
\hline \multirow[t]{3}{*}{4} & $\mathrm{U}$ & 6 & 4 & 0 & 10 \\
\hline & Ž & 3 & 1 & 2 & 6 \\
\hline & $\sum$ & 9 & 5 & 2 & 16 \\
\hline 5 & $\bar{U}$ & 6 & 1 & 0 & 7 \\
\hline
\end{tabular}




\begin{tabular}{|l|c|l|l|l|l|}
\hline & $\check{Z}$ & 0 & 0 & 0 & 0 \\
\cline { 2 - 6 } & $\sum$ & 6 & 1 & 0 & 7 \\
\hline
\end{tabular}

Tab. č. 4: Hodnoticí výroky z hlediska způsobu komunikace

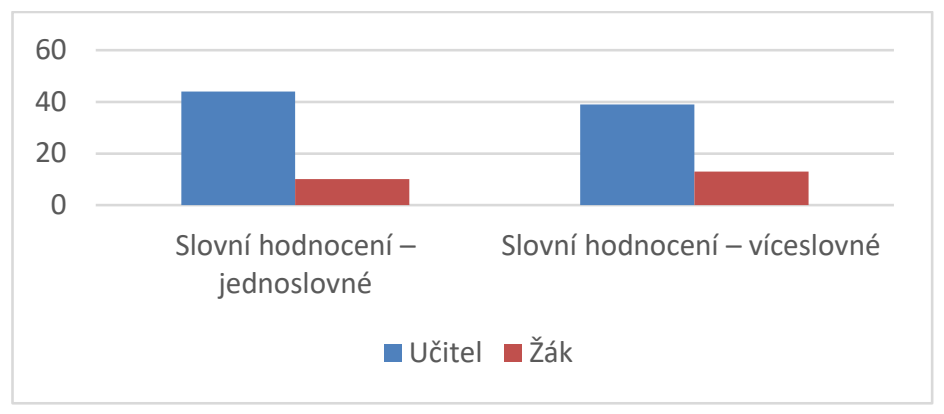

Graf č. 4: Celkový počet hodnotícich výroků z hlediska způsobu komunikace

Do skupiny hodnotících výroků z hlediska způsobu komunikace jsme zařadili verbální hodnocení, neverbální hodnocení a grafické hodnocení. Grafické projevy hodnocení jsme předpokládali v podobě obrázků, grafů, symbolů či barev. S ohledem na zaměření článku však byly analyzovány pouze kategorie vztahující se ke slovnímu hodnocení. V tabulce pro přehled uvádíme také neverbální hodnocení, které př̌edstavuje oceňující potlesk žáků na základě výzvy učitele. Ve snaze o detailnější rozlišení slovních výpovědí bylo verbální hodnocení dále kategorizováno na hodnocení jednoslovné a víceslovné. Do kategorie jednoslovného hodnocení nejčastěji patřili výroky typu výborně, dobře, ano, ne, špatně, krásně aj. Ve sledovaných hodinách bylo identifikováno celkem 115 hodnotících výroků, 83 od učitele a 32 vyslovených žáky. Z toho tvořilo 44 jednoslovných hodnotících výroků učitele a 10 výpovědí žáků. Víceslovné hodnocení se ve sledované výuce vyskytovalo méně než hodnocení jednoslovné. Celkem 39 hodnotících tvrzení bylo vysloveno učitelem a 13 výpovědí patřilo žákům.

\begin{tabular}{|l|c|c|c|c|c|}
\hline $\begin{array}{l}\text { Číslo } \\
\text { hodiny }\end{array}$ & $\begin{array}{l}\text { Nositel } \\
\text { dění }\end{array}$ & $\begin{array}{l}\text { Pozitivní } \\
\text { hodnocení }\end{array}$ & $\begin{array}{l}\text { Negativní } \\
\text { hodnocení }\end{array}$ & $\begin{array}{l}\text { Neutrální } \\
\text { hodnocení }\end{array}$ & Celkem \\
\hline \multirow{4}{*}{} & $\mathrm{U}$ & 15 & 12 & 0 & 27 \\
\cline { 2 - 6 } & $\check{Z}$ & 5 & 12 & 0 & 17 \\
\cline { 2 - 6 } & $\sum$ & 20 & 24 & 0 & 44 \\
\hline \multirow{4}{*}{3} & $\mathrm{U}$ & 18 & 20 & 0 & 38 \\
\cline { 2 - 6 } & $\check{Z}$ & 3 & 2 & 0 & 5 \\
\cline { 2 - 6 } & $\sum$ & 21 & 22 & 0 & 43 \\
\hline 3 & $\mathrm{U}$ & 7 & 2 & 2 & 11 \\
\cline { 2 - 6 } & $\check{Z}$ & 4 & 0 & 0 & 4 \\
\cline { 2 - 6 } & $\sum$ & 11 & 2 & 2 & 15 \\
\hline 4 & $\mathrm{U}$ & 9 & 0 & 2 & 11 \\
\hline
\end{tabular}




\begin{tabular}{|c|c|c|c|c|c|}
\hline \multirow{3}{*}{5} & $\check{Z}$ & 3 & 0 & 2 & 5 \\
\cline { 2 - 6 } & $\sum$ & 12 & 0 & 4 & 16 \\
\hline \multirow{5}{*}{5} & $\mathrm{U}$ & 6 & 1 & 0 & 7 \\
\cline { 2 - 6 } & $\check{Z}$ & 1 & 0 & 0 & 1 \\
\cline { 2 - 6 } & $\Sigma$ & 7 & 1 & 0 & 8 \\
\hline
\end{tabular}

Tabulka č. 5: Hodnoticí výroky z hlediska citového zabarvení

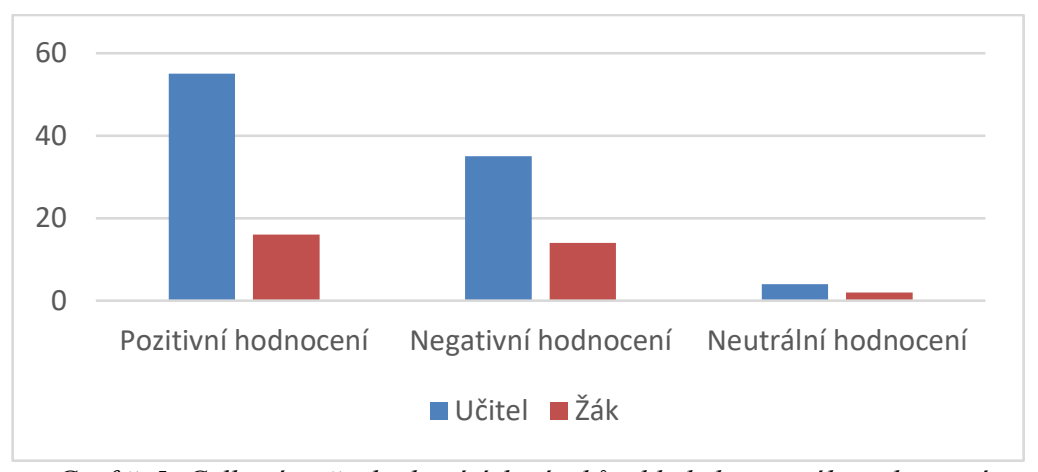

Graf č. 5: Celkový počet hodnotícich výroků z hlediska citového zabarvení

Sledované hodnocení bylo analyzováno rovněž z hlediska citového zabarvení. Zde byly zaznamenány hodnotící projevy ve třech podskupinách, a to pozitivní hodnocení, negativní hodnocení a neutrální hodnocení. $Z$ celkového počtu 125 hodnotících výroků bylo 70 pozitivně zabarvených, 49 negativně zabarvených a 6 neutrálních. Při porovnání kategorií dle nositele dění patřilo 55 pozitivních hodnotících projevi̊ učiteli a 16 hodnotících projevů ze strany žáků. Učitel vyslovil celkem 35 negativně zabarvených hodnotících výroků a žáci se při hodnocení negativně projevili ve 14 situacích. Neutrální hodnocení mělo z hlediska výskytu nejnižší četnosti. Učitel vyslovil 4 neutrálně zabarvené hodnotící výroky a žáci 2.

\begin{tabular}{|l|c|c|c|c|c|}
\hline $\begin{array}{c}\text { Číslo } \\
\text { hodiny }\end{array}$ & $\begin{array}{c}\text { Nositel } \\
\text { dění }\end{array}$ & $\begin{array}{c}\text { Se } \\
\text { zdůvodněním }\end{array}$ & $\begin{array}{c}\text { Bez } \\
\text { zdůvodnění }\end{array}$ & $\begin{array}{c}\text { S návrhy } \\
\text { k překonání } \\
\text { nedostatků }\end{array}$ & Celkem \\
\hline \multirow{4}{*}{1} & $\mathrm{U}$ & 6 & 19 & 1 & 26 \\
\cline { 2 - 6 } & $\check{Z}$ & 3 & 5 & 0 & 8 \\
\cline { 2 - 6 } & $\Sigma$ & 9 & 24 & 1 & 34 \\
\hline \multirow{4}{*}{2} & $\mathrm{U}$ & 7 & 25 & 6 & 38 \\
\cline { 2 - 6 } & $\mathrm{Z}$ & 2 & 3 & 0 & 5 \\
\cline { 2 - 6 } & $\Sigma$ & 9 & 28 & 6 & 43 \\
\hline 3 & $\mathrm{U}$ & 4 & 8 & 0 & 12 \\
\cline { 2 - 6 } & $\check{Z}$ & 0 & 4 & 0 & 4 \\
\cline { 2 - 6 } & $\Sigma$ & 4 & 12 & 0 & 16 \\
\hline 4 & $\mathrm{U}$ & 0 & 6 & 2 & 8 \\
\hline
\end{tabular}




\begin{tabular}{|l|c|c|c|c|c|}
\hline \multirow{3}{*}{5} & $\check{Z}$ & 0 & 3 & 0 & 3 \\
\cline { 2 - 6 } & $\Sigma$ & 0 & 9 & 2 & 11 \\
\hline \multirow{5}{*}{5} & $\mathrm{U}$ & 1 & 7 & 0 & 8 \\
\cline { 2 - 6 } & $\check{Z}$ & 0 & 0 & 0 & 0 \\
\cline { 2 - 6 } & $\Sigma$ & 1 & 7 & 0 & 8 \\
\hline
\end{tabular}

Tab. č. 6: Hodnoticí výroky z hlediska zpětné vazby

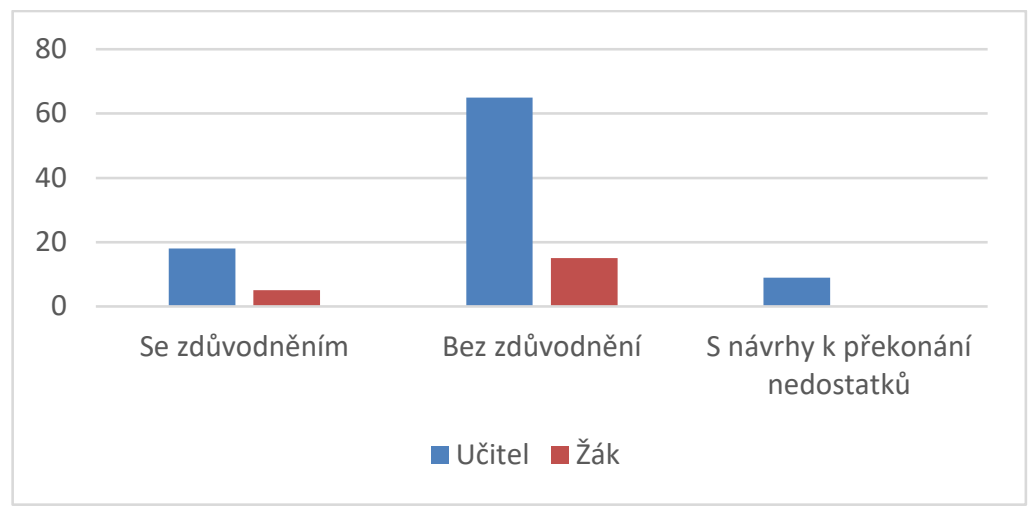

Graf č. 6: Celkový počet hodnoticich výroki̊ z hlediska zpětné vazby

V kontextu problematiky komunikace a interakce ve výuce jsme dále analyzovali výskyt hodnotících výroků $\mathrm{z}$ hlediska poskytnutí zpětné vazby. $\mathrm{Z}$ celkového počtu 112 hodnotících výroků bylo 92 vysloveno učitelem a 20 žáky. Hodnocení se zdůvodněním bylo identifikováno celkem 23 krát, z toho 18 výroků vyslovil učitel a 5 výroků žáci. Hodnocení bez zdůvodnění bylo ve sledované výuce zaznamenáno celkem 80 krát. Souhrnně 65 hodnotících tvrzení vyslovil učitel a 15 žáci. Hodnotící výroky obsahující návrhy k překonání nedostatků byly identifikovány celkem 9krát, všechny vysloveny výhradně učitelem.

\begin{tabular}{|l|c|c|c|c|}
\hline $\begin{array}{c}\text { Č́íslo } \\
\text { hodiny }\end{array}$ & $\begin{array}{c}\text { Nositel } \\
\text { dění }\end{array}$ & $\begin{array}{c}\text { Uživání } \\
\text { posuzujícího } \\
\text { jazyka }\end{array}$ & $\begin{array}{c}\text { Užíání } \\
\text { popisného } \\
\text { jazyka }\end{array}$ & Celkem \\
\hline \multirow{4}{*}{1} & $\mathrm{U}$ & 20 & 7 & 27 \\
\cline { 2 - 5 } & $\check{Z}$ & 12 & 5 & 17 \\
\cline { 2 - 5 } & $\sum$ & 32 & 12 & 44 \\
\hline \multirow{4}{*}{3} & $\mathrm{U}$ & 7 & 4 & 11 \\
\cline { 2 - 5 } & $\check{Z}$ & 4 & 0 & 4 \\
\cline { 2 - 5 } & $\sum$ & 11 & 4 & 15 \\
\hline \multirow{4}{*}{3} & $\mathrm{U}$ & 7 & 4 & 11 \\
\cline { 2 - 5 } & $\check{Z}$ & 4 & 0 & 4 \\
\cline { 2 - 5 } & $\sum$ & 11 & 4 & 15 \\
\hline \multirow{2}{*}{4} & $\mathrm{U}$ & 7 & 3 & 10 \\
\hline
\end{tabular}




\begin{tabular}{|c|c|c|c|c|}
\hline \multirow{3}{*}{5} & $\check{Z}$ & 3 & 2 & 5 \\
\cline { 2 - 5 } & $\sum$ & 10 & 5 & 15 \\
\hline \multirow{3}{*}{5} & $\mathrm{U}$ & 6 & 1 & 7 \\
\cline { 2 - 5 } & $\check{Z}$ & 1 & 0 & 1 \\
\cline { 2 - 5 } & $\sum$ & 7 & 1 & 8 \\
\hline
\end{tabular}

Tab. č. 7: Hodnotící výroky z hlediska užití jazyka

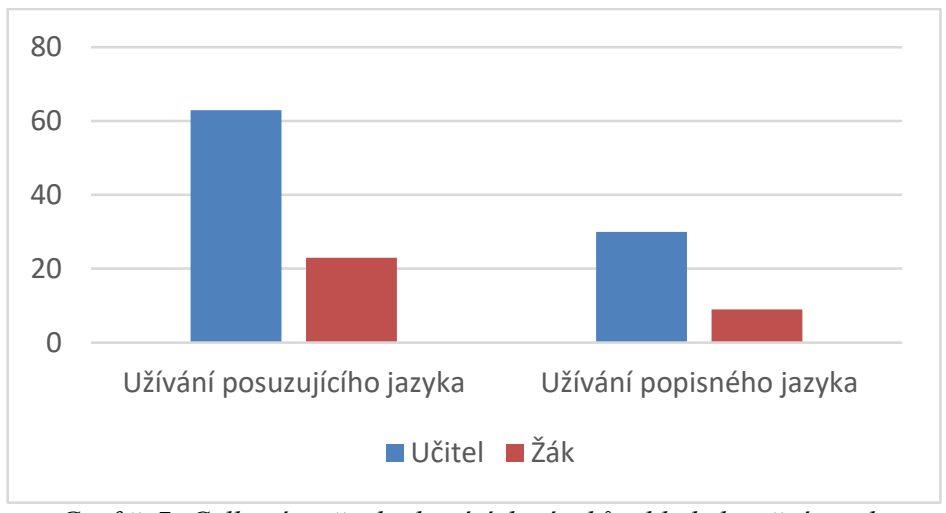

Graf č. 7: Celková počet hodnotících výroki̊ z hlediska užití jazyka

Poslední sledovanou kategorií bylo hodnocení z hlediska užití jazyka. $V$ tomto př́padě bylo rozlišováno, zda hodnotitel užívá posuzující nebo popisný jazyk. $Z$ celkového počtu 125 hodnotících výroků bylo 86 formulováno posuzujícím jazykem a 39 popisným jazykem. Posuzující jazyk užívala častěji učitelka - 63krát, než žák - 23krát. Popisný jazyk byl v hodnotících výrocích učitelky zaznamenán 30 krát, zatímco u žáků 9krát.

\section{Shrnutí a diskuse}

Ve výzkumném šetření byly zkoumány a sumarizovány odpovědi na následující výzkumné otázky:

1. Kdo je nositelem dèni při hodnoticích aktivitách ve výuce technické výchovy?

Nositel pedagogického dění v kontextu hodnocení uvádí, jakou mírou aktivity se podílí jednotliví činitelé na edukačním procesu. $Z$ výsledků šetření vyplývá, že učitelka je nejaktivnějším článkem procesu. Tento výsledek nepovažujeme za negativní, ale za zcela přirozený jev daný specifickými podmínkami edukace v prvním ročníku. Obzvláště první pololetí školního roku je dobou adaptace žáků na školní podmínky a pravidla, postupné seznamování s metodami, organizačními formami i specifickými pravidly uplatňovanými ve výuce předmětu Praktické činnosti. V následujících ročnících př̌edpokládáme snížení rozdílu v aktivitě učitele a žáků. Tento předpoklad mimo jiné vychází z výsledků 
výzkumného šetření zaměřeného na interakci mezi učitelem a žákem na primární škole (Stolinská, 2012) které naznačily posun podílu aktivity učitele a žáka ${ }^{7}$.

Z hlediska objektu hodnocení je možné konstatovat, že učitelka nejčastěji hodnotí dívky, pak chlapce, a v poslední řadě skupiny žáků. Uvedený výsledek je však ovlivněn vyšším počtem dívek ve trrídě. Zpočátku jsme předpokládali vliv zasedacího pořádku, nicméně dle výpovědi učitelky je zasedací pořádek každou vyučovací hodinu odlišný, tudíž tuto skutečnost není možné ověřit. Do výsledků rovněž významně zasáhl fakt, že vzhledem $\mathrm{k}$ metodě nezúčastněného pozorování nebylo možné značné množství výroků přiřadit k uvedeným skupinám. $Z$ tohoto důvodu je uvádíme jako anonymní hodnocení. Při porovnání počtu hodnotících tvrzení učitelky a žáků je zajímavý fakt, že zatímco učitelka hodnotí nejčastěji dívky, u žákủ je tomu přesně naopak. Žáci nejčastěji hodnotili skupiny žáků, pak chlapce a v poslední řadě dívky.

2. Jaký je charakter hodnotícich činností žáka?

Z hlediska procesu učení byla identifikována převaha sumativně orientovaných hodnotících výroků, přičemž opět převládaly výroky učitelky nad výroky žáků. Převahu sumativního hodnocení zdůvodňujeme zejména snahou učitelky ohodnotit práci většiny žáků ve tř́́dě $\mathrm{v}$ závěrečné části hodiny. Vyšší zaznamenaný rozdíl byl zaznamenán u výrokủ zaměřených formativně, kdy se učitelka snažila účelně ovlivnit jednotlivé kroky postupu práce žáků i celkový proces tvorby tak, aby bylo dosaženo stanoveného cíle. Zde jsme předpokládali postupný růst počtu formativně orientovaných hodnotících výroků ze strany žáků, vzhledem $\mathrm{k}$ postupnému získávání zkušeností a osvojování dovednosti hodnocení. Tento předpoklad se nám však nepotvrdil. Jak uvádí V. Laufková, (2016, formativní hodnocení je žáky i učiteli často spojováno se spravedlivostí, logicky je tedy žáky i lépe přijímáno. $Z$ toho důvodu předpokládáme postupné zvýšení frekvence výskytu formativního hodnocení i ze strany žáků, a to i přesto, že je formativní hodnocení časově náročnější a jeho realizace může být ve výuce „na úkor učeni““. (Heritage, 2007)

3. Jaké typy hodnocení z hlediska komunikace se vyskytuji ve výuce technické výchovy?

Ve snaze postihnout charakteristiku hodnocení z hlediska způsobu komunikace jsme se rozhodli rozlišovat pouze hodnocení verbální a neverbální. Přičemž neverbální hodnocení ve výzkumném šetření představovalo výhradně vzájemné ocenění žáků ve formě potlesku. Slovní hodnocení dále členíme na hodnocení víceslovné a jednoslovné. Jednoslovné hodnocení se ve sledovaných hodinách vyskytovalo častěji, opět převažovalo ke konci činnosti, kdy učitelka velmi stručně hodnotila práci velkého množství žáků.

V návaznosti na teoretická východiska byly analyzovány četnosti hodnotících výroků z hlediska citového zabarvení. Zde je možné konstatovat fakt, že ve výuce převažovalo pozitivní hodnocení, zejména ze strany učitelky. U žáků byl rozdíl v četnosti mezi pozitivními a negativními výroky nejnižší. A to $\mathrm{z}$ toho důvodu, že učitelka častěji podněcovala žáky $\mathrm{k}$ hodnocení formou „dotazu na chyby“. Minimálních četností dosahovala neutrálně formulovaná hodnocení, a to jak v prŕípadě učitelky, tak žáků. V souvislosti s tímto považujeme za vhodné doplnit, že byly analyzovány i výzvy a dotazování učitelky, které byly velmi často kladené účelově (kladně či záporně), což ovlivňovalo i následné hodnotící výroky žáků.

\footnotetext{
${ }^{7}$ Reformní představou bylo, aby se aktivita mezi učitele a žáka dělila rovným dílem. Bellack ve své mikroanalýze člení aktivitu na $85 \%$ pro učitele a $15 \%$ pro žáka, jeho výzkum však nebyl zaměřen na primární školu.
} 
Z hlediska užití jazyka bylo vyčleněno a analyzováno užívání popisného a posuzujícího jazyka. Jak $\mathrm{v}$ prípadě učitelky, tak $\mathrm{v}$ př́ípadě žáků převažovalo užití posuzujícího jazyka, který tzv. „,nálepkuje“ žáky a nevede k poskytnutí adekvátní zpětné vazby. Při analýze výroků z hlediska zpětné vazby je možné konstatovat, že převažovala hodnotící tvrzení bez zdůvodnění, což je v kontextu rozvoje sebehodnotících aktivit žáků poměrně negativní zjištění. Hodnocení žáků se zdůvodněním představovalo pouze minimální všech výroků učitele. Nejnižších hodnot dosahovalo hodnocení doplněné návrhy $\mathrm{k}$ překonání nedostatků. To se u žáků nevyskytovalo vůbec. Velmi často se vyskytoval jev, kdy učitelka velmi často užívala výroky „,výborně“ nebo „dobře“ aniž by byly proneseny s pochvalným důrazem. Funkce těchto výroků je tedy pro žáky informací o tom, že je možné se posunout dál, nicméně nenese významnější zprávy o výkonu. Tento jev ve svém výzkumu rovněž identifikovali autoři K. Šed’ová a R. Švaříček ${ }^{8}$ (2010).

\section{Závěr}

Technická výchova je velmi specifickým předmětem, který představuje pro žáky jednu z mála srozumitelných paralel mezi osvojováním teoretických poznatkủ a jejich následným praktickým uplatněním $\mathrm{v}$ životě. Na primární škole je jedním z předmětů představující kompenzaci ke znalostně orientovaným disciplínám. Současně svým interdisciplinárním charakterem je velmi blízká filosofii primární školy. Technická výchova a uplatnitelnost jejího obsahu v každodenním životě žáka poskytuje ideální podmínky k rozvoji jeho osobnostních kvalit, včetně dovednosti hodnotit průběh a výsledky vlastní práce.

Dovednost (sebe)hodnocení a vnitřní svět osobnosti žáka jsou dvě neoddělitelné součásti. Žák jako aktivní účastník celého procesu vývoje osobnosti se v souladu s aktuální vzdělávací politikou má podílet na ovlivňování a utváření svého Já a ve snaze o identifikaci a následné uspokojování specifických potřeb dosahovat vymezených individuálních cílů a naplňovat tak smysl svého života. Úvahy ostatních i vlastní osobě se projevují jednak v podobě pozitivního či negativního citového vztahu a jednak v podobě rozumového hodnocení vyjádřeného konkrétním hodnocením výkonu. Školní výkon se tedy často stává prostředkem potvrzení vlastní hodnoty žáka.

Cílem článku bylo prezentovat dílčí výsledky realizovaného výzkumného šetření zaměřeného na analýzu hodnotících procesů u žákủ v prvním ročníku základní školy tak, aby bylo možné postihnout jejich principy a specifika, naleznout odpovědi na stanovené výzkumné otázky a naznačit další směr výzkumného šetření. V návaznosti na teoretická východiska byly vytvořeny kategorie podrobně mapující specifika hodnocení v procesu pedagogické komunikace. Na základě Bellackovy a Flandersovy interakční analýzy byl vytvořen a ověřen specifický výzkumný nástroj určený $\mathrm{k}$ analýze hodnotících výroků učitele i žáků.

Předkládané dílčí výsledky realizovaného šetření podávají dosavadní obraz hodnotících procesů ve zkoumané třídě. Vzhledem $\mathrm{k}$ tomu, že výzkum nadále pokračuje, předpokládáme kvalitativní posun ve smyslu poskytování většího prostoru žákům při realizaci hodnotících aktivit a postupný rozvoj sebehodnocení. Současně si uvědomujeme značné množství determinant, které ovlivňují výuku a odlišují edukační realitu od „ideální“ představy nejen hodnotících aktivit, ale celého edukačního procesu. Zásadní otázkou je, zda jsou proklamované teoretické vize realizovatelné ve stávajících podmínkách.

\footnotetext{
${ }^{8}$ Realizovaný terénní výzkum byl zaměřen na komunikaci na druhém stupni ZŠ.
} 


\section{Literatura}

Allhoff, D.W. \& Allhoff. W. (2008). Rétorika a komunikace. Praha: Grada.

Bellack, A. A., et al. (1966). The Language of the Classroom. New York: Teachers College Press.

Dvořáková, M. (2007). Hodnocení ve vyučování. In. Vališová, A. \& Kasíková, H. et al. Pedagogika pro učitele. s. 249-270. Praha: Grada.

Gavora, P. (2001). Diagnostikovanie a hodnotenie žiaka vo vyučovaní. In. Předškolní a primární pedagogika. Kolláriková, Z. \& Pupala, B. et al. Praha: Portál.

Helus, Z., Hrabal, V., Kulič, V., \& Mareš, J. (1979). Psychologie školní úspěšnosti žáků. Praha: SPN.

Hendl, J. (2012). Kvalitativní výzkum: základní teorie, metody a aplikace. Praha: Portál. Heritage, M. (2007). Formative Assessment: What Do Teachers Need to Know and Do? Phi Delta Kappan, 89(2), 140-145.

Chráska, M. (2007). Metody pedagogického výzkumu: základy kvantitativního výzkumu. Praha: Grada.

Kolář, Z., \& Šikulová, R. (2009). Hodnocení žáků. Praha: Grada.

Koštálová, H., Miková, Š., Stang, J. (2012). Školni hodnocení žáků a studentů: se zaměrením na slovni hodnocení. Praha: Portál.

Kožuchová, M. (1993). Pracovná výchova a technické vzdelávanie na ZŠ. Bratislava: Univerzita Komenského.

Kratochvílová, J. (2011). Systém hodnocení a sebehodnocení žáků: zkušenosti z České republiky i Evropských škol. Brno: MSD.

Kropáč, J., st. \& Kropáč, J., ml. (2009). Hodnocení techniky jako obsah výuky technických předmětů na ZŠ. Trendy ve vzdělávání 2009 [online]. Olomouc: Univerzita Palackého v Olomouci, Katedra technické a informační výchovy, 2009, 2(1), 88-91 [cit. 2017-05-13]. Dostupné z: http://tvv-journal.upol.cz/pdfs/tvv/2009/01/19.pdf

Kropáč, J., st., Kropáč, J., ml. \& Plischke, J. Hodnocení techniky - předpopklad komplexnosti výuky technických předmětů. Journal of technology and Inofrmation Education [online]. Olomouc: Univerzita Palackého v Olomouci, Katedra technické a informační výchovy, 2010, 2(1), 24-28 [cit. 2017-05-13]. Dostupné z: http://jtie.upol.cz/cz/artkey/jti-201001-0004_HODNOCENI_TECHNIKY__PREDPOKLAD_KOMPLEXNOSTI_VYUKY_TECHNICKYCH_PREDMETU.php

LAUFKOVÁ, V. (2016). Formativní hodnocení. Praha: Pedagogická fakulta, Univerzita Karlova v Praze. Disertační práce. Vedoucí práce PhDr. Karel Starý, Ph.D.

Mareš, J., Slavík, J, Svatoš, T. \& Švec, V. (1996). Učitelovo pojetí výuky. Brno: Masarykova univerzita.

MŠMT. Strategie vzdělávací politiky v ČR do roku 2020. (2014). Dostupné z: http://www.msmt.cz/uploads/Strategie_2020_web.pdf

Nelešovská, A. (2005). Pedagogická komunikace v teorii a praxi. Praha: Grada.

Novotný, J. \& Honzíková, J. (2014). Technické vzdělávání a rozvoj technické tvořivosti. Ústí nad Labem: Univerzita J. E. Purkyně.

Sedláčková, H., Syslová, Z. \& Štěpánková, L. (2012). Hodnoceni výsledků předškolního vzdělávání. Praha: Wolters Kluwer Česká republika.

Slavík, J. (1999). Hodnocení v současné škole: východiska a nové metody pro praxi. Praha: Portál. 
Spilková, V. (2012). Výzvy, které přináší osobnostně rozvíjející pojetí vzdělání pro školu, učitele a vzdělávací politiku. In. Helus, Z. \& Lukášová, H. Proměny pojetí vzdělávání a školniho hodnocení: filozofická východiska a pedagogické souvislosti. Praha: Asociace waldorfských škol ČR. s. 41-70.

Stolinská, D. (2012). Interakce učitel-žák v proměnách primárniho vzdělávání. Olomouc: Pedagogická fakulta, Univerzita Palackého v Olomouci. Disertační práce. Vedoucí práce Prof. PhDr. Alena Nelešovská, CSc.

Stuchlíková, I. (2002). Základy psychologie emocí. Praha: Portál.

Šed'ová, K., \& Švaříček, R. (2010). Zamlčené hodnocení: zpětná vazba ve výukové komunikaci na druhém stupni základní školy. Studia Paedagogica, 15(2), 61-86.

Škára, I. (1993). Úvod do teorie technického vzdèlávání a technické výchovy žákủ základní školy. Brno: Masarykova univerzita.

Watzlawick, P., Bavelas, J. B. \& Jackson, D. D. (2011). Pragmatics of Human Communication. New York: W. W. Norton. 